\title{
Family Business Adapting a New Digital-Based Economy: Opportunities and Challenges for Future Research
}

\author{
Laura Zapata-Cantu ${ }^{1}$ - Ramón Sanguino² ${ }^{2}$ Ascensión Barroso ${ }^{2}$. \\ Laura Nicola-Gavrilă ${ }^{3}$
}

Received: 19 April 2021 / Accepted: 27 November 2021

(c) The Author(s), under exclusive licence to Springer Science+Business Media, LLC, part of Springer Nature 2021

\begin{abstract}
Firms need to transform dramatically to maintain their operations and survive. The pandemic has shown how family businesses (FBs) are solving complex problems faster than non-family. They have demonstrated the flexibility to transform and adapt because of their closeness to the firm's processes and management and their social network inside and outside organizations that allow them to respond quickly to market needs based on a fast-making decisions process. FBs' knowledge, which is embedded in their values, making decisions process, and remaining for generations, requires resilient and robust management. The relationship between family values and FB management differentiates by their complexity and generational aspect. These relations demonstrate that personal values can influence professionalization, succession, and innovation processes. In this regard, there is a lack of research to understand the findings, practices, and processes associated with managing the knowledge flows through which FBs execute innovation strategies and to build on professionalization and succession capabilities that could provide different avenues of innovation and adaptation for dealing with turbulent and uncertain times. This editorial intends to provoke discussion on what we know about family businesses and how they face different challenges in a complex world to survive. FBs must develop adaptive strategies and strengthen crucial processes to generate a competitive and sustainable advantage. Knowledge management provides models and tools to reinforce tacit knowledge management's relevance in the professionalization and succession processes. Knowledge management becomes critical in an era in which uncertainty seems to be permanent.
\end{abstract}

Part of Topical Collection "Enhancing the Adaptability of Family Businesses to the Knowledgebased Economy"

Laura Zapata-Cantu

laura.zapata@tec.mx

Extended author information available on the last page of the article

Published online: 18 January 2022 
Keywords Family businesses $\cdot$ Knowledge management $\cdot$ Succession ·

Professionalization · Innovation

\section{Introduction}

Organizations question themselves with uncertainty about the future. Since the end of the twentieth century, we have lived in constant change. Businesses have been forced to achieve technological advances, to understand and adapt to consumer needs, and today, to face an unprecedented pandemic, COVID-19. At the same time, businesses need to continuously transform and reconfigure their capabilities (Carayannis et al., 2014; Teece, 2007). It turns essential to discuss how to survive in the competitive global marketplace with a powerful economic impact. In this regard, knowledge management plays a dominant role in supporting organizations in knowledge and digital-based economies, regardless of industry or size. Companies must acquire, create, disseminate, and use knowledge more effectively to create a sustainable competitive advantage (Del Giudice et al., 2010).

In the pre-COVID-19 era, family and non-family businesses have been pressed to participate in globalization, achieve technological advances, and innovate. In a COVID-19 age, these challenges are becoming exponential. Firms have had to transform dramatically to continue their operations, to maintain, and to survive. This situation is not exclusively for non-family businesses. The pandemic has shown how family businesses (FBs) are solving complex problems faster than non-family. De Massis and Rondi (2020) expose that the pandemic and its social and economic repercussions are triggering particularly salient FB challenges.

In a post-pandemic global economy, family businesses play a significant role. They create, use, and allocate regional factors and interact with their environment, thus enabling them to substantially affect GDP, employment, and internationalization (Basco, 2015). It is estimated that these companies account for 85 percent of all companies worldwide (Botero et al., 2015), 70\%-90\% of the annual global product (GDP), and between 50 and $80 \%$ of all jobs in a majority of countries (Firfiray \& Gomez-Mejia, 2021).

A challenge that before the pandemic, FB conceive as critical but not urgent is leadership succession. Family owners typically want their firms to last for generations, and they can make long-term investments without worrying about shareholders pursuing immediate profits. A vast cohort of senior FB leaders have suddenly passed away or will leave the business earlier than expected, either deliberately or inadvertently, owing to a souring environment that will require new perspectives and stamina. As a result of the COVID-19, considerable implications on FB management and alternatives to internal generational transition have also come up, considering external or heterogeneous types of succession. This challenge has brought with it a disruptive way of thinking, direction, and acting in FB.

The growth and long-term survival of family firms depend on the entrepreneurial abilities of the individuals who own and manage these businesses and their ability to build functional business models that effectively capture and 
redistribute value-added to cope with the challenges that the current business environment presents (Carayannis et al., 2014).

FBs are forward-looking and oriented to grow over generations (Miroshnychenko et al., 2020). However, in current challenging times, FBs are more likely to feel nostalgic for the golden age of the past (backward-looking), leverage their family history and tradition, and focus on keeping their business alive by navigating uncertainty rather than pursuing growth. Similarly, the intention to hand the company to the next generation may conflict with the family's need to involve outsiders in the ownership and leadership team to keep the business alive. There is a need to review how the pandemic may affect the purpose of the growth of FB and how internal social changes could positively impact their survival.

COVID-19 and its aftermath are triggering challenges that, although potentially affecting any business, are particularly salient for FBs. It is necessary to reinforce the relevance for $\mathrm{FB}$ to highlight their unique characteristics such as family values, social ties, and internal and external social networks. There is a clear distinction between those who have to pursue professionalization and manage their tacit knowledge to leverage succession and innovation processes. This formalization has allowed faster making decisions and organizational transformation.

Given the need to be flexible to change and adversity, it would equally be necessary to develop strategies that reflect adaptability and build upon the strengths in the firm's capabilities and knowledge resources. For FB owners, these steps entail a deeper understanding of the external environment they operate in and strong knowledge of their firm's strengths. In these times, family businesses have shown the flexibility to transform and adapt as fast as non-family businesses. Their closeness to the firm's processes and management has allowed fast making decisions. Their social network inside and outside organizations has allowed them to respond quickly to market needs and changes.

Knowledge assets, difficult to imitate and transfer, are today the source that allows organizations to obtain better results than competitors, compared to property assets, which were the traditional basis for obtaining competitive advantages. In the FB context, the important role of the founder, learning, and succession should be highlighted: The founder is the person capable of transmitting the culture that prompted him to create the company and continue with the business, being the main source of knowledge in the family business. As the founder is linked to the company for a long time, he will facilitate the transmission of his knowledge and entrepreneurial orientation, causing learning by the successors. In this way, when the succession process occurs, knowledge is transferred to the next generation, shaping the culture of the company (Bañegil et al., 2013). Therefore, knowledge sharing also strengthens family firms' ability to pursue entrepreneurial opportunities, which are necessary to survive and preserve the capacity to create value over time (Pittino et al., 2017).

Following these ideas, this editorial intends to provoke discussion on what we know about family businesses and how they face different challenges in a complex world to survive. FBs must develop adaptive strategies and strengthen crucial processes to generate a competitive and sustainable advantage. Knowledge 
management provides models and tools to reinforce tacit knowledge management's relevance in the FBs professionalization and succession processes. Knowledge management becomes critical in an era in which uncertainty seems to be permanent.

\section{How to Enhance Adaptive Strategies in Family Firms?}

FB is the most ubiquitous business organization in any world economy (Burkart et al., 2003). This kind of firm follows distinct strategies that differentiate them from non-FBs, such as long-term orientation, risk avoidance, preference for equity financing, and commitment to frugal innovation (Le Breton-Miller \& Miller, 2006; Sirmon \& Hitt, 2003). FBs have unique resources and capabilities derived from the interaction between family and business, potentially yielding a competitive advantage (Habbershon \& Williams, 1999; Habbershon et al., 2003).

To face the current challenging environments, firms need to create dynamic capabilities that can reconfigure existing resources and change ways of doing things to sustain or redefine the firm's competitive advantage (Helfat \& Winter, 2011; Winter, 2003). The presence of dynamic capabilities can safeguard firm sustainability and growth within turbulent and dynamic business environments. Previous work highlights that family businesses can nurture distinctive dynamic capabilities due to family control (Chirico \& Nordqvist, 2010). Additionally, familiness resources play a role in creating dynamic capabilities in the family business to create competitive advantages and facilitate ongoing growth (Glyptis et al., 2021).

In these dynamic and uncertain environments, Hitt et al. (2020) found that firms were more willing to engage in riskier entrepreneurial strategies versus more incremental advantage-based strategies when developing solid relational capital with essential stakeholders. To manage complex problems, FB may be required to manage resources and stakeholders more effectively in the post-pandemic era. Additionally, firms need the agility to effectively design and implement strategic changes, which involves fluidity, speed, and mindsets that encourage innovative thinking and resilience. Thus, the sensing, seizing, and transforming components of dynamic capabilities (Teece, 2007) are even more required in post-pandemic era.

One essential factor determining family and other firms' survival is their level of adaptability to address existing and emergent challenges (Alonso et al., 2019). Adaptability is essential for regulating and integrating change in family systems concerning their inner or outer environment and solving their problems. Chirico and Salvato (2008) underline the importance of "recognizing enablers of dynamic organizational adaptation" (p. 169), especially for FBs, as triggers of sustainable competitive advantage, the significance of growth, and generational renewal.

Knowledge management processes of the FBs are affected by environmental factors ( $\mathrm{Su} \&$ Daspit, 2021). To adapt to environmental changes, FBs need to reconfigure and realign their knowledge capabilities, such as knowledge exploration (creation), retention, and exploitation (transfer and utilization) 
(Martinez-Conesa et al., 2017). For instance, the relationship between family influence and knowledge application when the environment is rapidly changing requires an "extra effort" toward knowledge application processes to survive uncertain times.

In this regard, we propose that FB knowledge capabilities must be recognized as dynamic and adaptive capabilities. For instance, knowledge accumulation is significant in FBs while generating value over time, mainly when a new generation controls the company (succession). Likewise, professionalization that embedded family values enable FBs to cope with a complex environment (Songini \& Gnan, 2015), increasing their profitability and obtaining a competitive advantage (Dieguez-Soto et al., 2016; Fang et al., 2012).

\section{Knowledge Management Processes as Adaptive Capabilities of Family Firms: Professionalization and Succession}

For Camfield and Franco (2019), there are relationships between personal values and the aspects of succession and professionalization and, therefore, in family firm management. Even though a family's presence in the business is assumed to ensure stable and trusting, long-lasting relationships with external and internal actors, accruing distinctive social capital (Arregle et al., 2007), and strong identification with the organization. In this connection, Morgan, and Gómez-Mejía (2014) expose that personal values are directly related to family firm management. One example is in family business succession personal values influence the decision to keep control in the next family generation. Another example is when a family decides to professionalize management by hiring a non-family professional (Chen et al., 2016).

What is relevant to point out is that family firms' knowledge in their values, making decisions process, and remaining for generations requires resilient and robust management: an effective knowledge management process to allow these organizations to adapt and response agilely. The relationship between family values and family firm management differentiates by the family's complexity and the generational aspect of each family firm. These relations demonstrate that personal values can influence professionalization and the family firm succession and innovation processes.

Family firms must create financial value over generations to survive long-term. The ability to do so largely depends on how they can use and combine their current knowledge to generate new knowledge. Elements of knowledge transfer across generations include moral values, competence values, and cognitive heuristics, which highlight types of knowledge that are foundational to the transgenerational success of the family firm (Su \& Daspit, 2021). The study of knowledge management within the family business literature has been approached from two perspectives: (1) understanding knowledge sharing within the family and (2) understanding the predictors and effects of knowledge sharing. Within the family, knowledge sharing was first incorporated into the family business literature by Cabrera-Suárez and colleagues (2001). They suggested that the knowledge that family businesses accumulate 
through different generations can be a strategic resource that can enhance the competitive advantage if transferred and augmented throughout the other generations. Building on Habbershon and William's work (1999) on familiness, Cabrera-Suárez and colleagues argue that the knowledge acquired and transferred between generations of family business owners and managers is one resource that helps differentiate families from non-family firms (Botero et al., 2021).

Nevertheless, empirical research on knowledge-management processes in family businesses and how they face the knowledge-based economy is still limited. The study of knowledge management began in the early 1990s - to understand how large firms create, share, and combine knowledge-making it crucial to competitiveness (Nonaka, 1991; Nonaka \& Takeuchi, 1995). Since then, research has explained its relationship to performance, exploring and exposing techniques, mechanisms, or processes at the individual and organizational level. However, knowledge management in the family business context has only been marginally studied.

\section{Knowledge Management Activities that Influence Family Firms}

Family firms should know how to generate and transfer knowledge, allowing them to be innovative and operationally efficient to seize opportunities and anticipate or mitigate threats that the current environment presents. In this sense, knowledge management should ensure sustainability and rapid adaptation to dynamic environments by family businesses.

Apart from that, family businesses have specific characteristics that can produce both the firm's strengths and weaknesses (Tagiuri \& Davis, 1996; Fuentes-Lombardo et al., 2011). Although sharing knowledge is essential, Zahra et al. (2007) point out some characteristics that limit this exchange. Specifically, the most valuable experience in a family business is usually possessed by a single family member or a limited number of members that increases the consolidation of power and control. In this way, a little exchange of experiences can smother the family businesses' capacity to develop an entrepreneurial orientation. Moreover, jealousy, which often appears when someone desires to have someone else's position, may cause a barrier to communication and deteriorating relations between family members, thereby causing a lower knowledge transfer (Cromie et al., 1995).

Fortunately, family businesses also possess specific characteristics that facilitate the exchange of knowledge. These characteristics are based on the family businesses' resources and capabilities. Amongst these, we can mention their commitment, confidence, trust, reputation, know-how, and a strong sense of identity (Cabrera-Suárez et al., 2001; Sirmon \& Hitt, 2003; Zahra et al., 2007). Moreover, these firms have a specific family language that allows them to communicate more efficiently and exchange more information in greater privacy (Hoffman et al., 2006). Family businesses may represent a robust social community, defined as a network of relationships among organization members that leads to open communication. In this community, personal contacts are the basis for exchanging knowledge (Zahra et al., 2007). Similarly, Botero et al. (2021) argue that the family system can influence knowledge sharing within family firms through at least two routes: In route 1, 
family characteristics (i.e., commitment of next generation, family trust and intergenerational relationships) impact the organizational culture, which in turn affects knowledge sharing. In route 2, the influence of the family (through generation in control) strengthens the relationship between culture and knowledge sharing within family firms.

Many researchers point to the lack of knowledge transfer and sharing studies in family firms (e.g., Mazzola et al., 2008; Giovannoni, 2011; Botero et al., 2021). In response to their call for more research on this issue, Barroso et al. (2013) conclude that knowledge is best transferred when family members value the following factors: trust between family members, commitment to the family business, intergenerational and intragenerational relationships, psychological ownership of the family business, successor's aspects and training, predecessor involvement in the successor training, organizational culture, and relationships with family business associations. This set of attributes influence knowledge transfer in family firms.

Letonja and Duh (2016) conclude that a family businesses' tacit knowledge, embedded in its founder, and its transmission is essential for building and sustaining competitive advantage since this type of knowledge is difficult to trade and imitate, scarce, appropriate, and specialized. The purpose of their research was to broaden the understanding of family businesses' tacit knowledge and its creation during the succession process by applying the concept of knowledge creation through the socalled SECI process. These authors suggest that tacit knowledge creation must be taken into consideration in a broader context of organizational knowledge creation during the succession process. To raise the total quality of a successor's knowledge and adding new knowledge, thus contributing to building the family business's competitive advantage.

For family firms, alliances represent a form of heightened entrepreneurial risktaking. However, an absence of research exists on the implications of forms of alliance governance for family firms. However, family firms rely on high levels of trust for the creation of knowledge. Knowledge creation suffers when family firms encounter complete contracts tied to attempts at high levels of trust. The negative interaction effect is robust for non-owner-run family firms (Bouncken et al., 2020).

\section{Knowledge Management as the Professionalization of Family Businesses}

Professionalization has been one of the critical challenges faced by family businesses and its effects on firm performance. Some studies indicate that a family firm's professionalization can be achieved through family members if care is taken in training and selecting those members that will one day work in firm management and take control of its strategic direction (Camfield \& Franco, 2019). For other authors, professionalization should occur by hiring non-family professionals. This solution has a significant impact on the family involvement in the firm management because it becomes limited.

For Dekker et al., (2013, p 86), professionalization is a construct of five different dimensions: financial control systems, non-family involvement in governance 
systems, human resource control systems, decentralization of authority, and toplevel activeness or the employment of non-family professionals (Polat, 2020). During the coronavirus pandemic, it has been notorious the professionalization of FBs boards and management teams and their alignment to make effective and fasten decisions. Hence, they should devise ways to professionalize their governance structures so that they align with the family's values as well as the scope of the business (Firfiray \& Gomez-Mejia, 2021).

For some FBs, firm professionalization follows its organizational life cycle, being shown through the increased complexity of the firm's operations and looking for more sophisticated organizational management systems. For instance, communication and transparency during a crisis enhance the reputation and corporate image of a firm (Firfiray \& Gomez-Mejia, 2021). Family firms need a communication strategy to demonstrate accountability by showing how they are adjusting their strategies to navigate the consequences of the pandemic.

The truth is professionalizing FBs carries a lot of tacit knowledge to manage. Organizational culture and work environment, which have been built on family values and generations, must be considered.

\section{Knowledge Sharing in Family Business Succession: How Knowledge Evolves Through Generations}

The planning for succession identified in the firms, principally in the larger ones, is noted that the satisfaction with the succession process is due to the adaptation and preparation of the successor (e.g., Brumana et al., 2017; De Massis et al., 2008; Vozikis et al., 2012). FBs unique characteristics imply that younger family members will eventually take over the business, building on the previous generation's knowledge (Cabrera-Suarez et al., 2001). This succession process is described as "the lengthiest strategic process for family firms" (Chirico, 2008). In this regard, knowledge management becomes critical for these firms where strategic knowledge is disseminated among the top management team and family members.

Knowledge transfer from the previous generation to the following is significant for managing the business. Meanwhile, the next generation has to add new knowledge and offer new perspectives to the family business. Just as it is necessary to share knowledge between different generations, it is also essential to share it among members of the same generation (Barroso et al., 2013).

By exploring the evolution of management practices and the processes of succession, Giovannoni et al. (2011) show that management accounting can affect the transfer of knowledge across generations and between the owner family and the management team, thus representing and reproducing the priorities, values, and vision of the entrepreneur.

Knowledge management is in transition (Ahonen et al., 2000). The first theories of knowledge management used the knowledge-carrying individual as the unit of analysis and defined knowledge in terms of discrete skills that can be codified and measured. The second-generation theories' key idea is that knowledge is embedded in and becomes constructed in collective practices. The challenge is to support the 
generation of new knowledge and competencies and report the results in a telephone company.

For the other part, understanding how knowledge is accumulated through generations is critical. Some studies indicate that only a third of family businesses successfully transition from one generation to the next, while only 5 percent of family firms are still creating value beyond the third generation (Chirico, 2008). Researchers argue that frequent causes of business failure fall under the general category of "business incompetence" caused by lack of knowledge or lack of capacity and willingness to create, share, transfer, and acquire the appropriate "knowledge" from generation to generation (Barroso et al., 2016).

After this literature review, it is significant to emphasize old and new FBs challenges that need further research. For instance, before the pandemic, FB was conceived as a critical but not urgent leadership succession. From a knowledge sharing perspective, the value of family knowledge and values passing through generations is vital. As a result of the COVID-19, considerable implications on FB management and alternatives to internal generational transition have also come up. This challenge has brought with it a disruptive way of thinking, direction, and acting in FB.

\section{Innovation and IT Crucial for Family Businesses Survival}

Over the following years, the priorities for the FBs are to improve profitability and diminish turnover, which implies the need to focus on innovative capabilities and the use of new IT and digital tools. Even if it is a family-owned business, a familyowned and managed business, or a family-owned and led business (Basco \& Pérez Rodríguez, 2011), innovation and digitalization hold the key to long-term success.

\section{Innovation and Knowledge Management in Family Firms}

Evidence shows how innovation processes and enablers differ from FBs to nonFBs. FBs are characterized by an "ability-willingness paradox" (De Massis et al., 2015), whereby their willingness to engage in innovation activities is lower than in non-FBs. However, they have a more remarkable ability to do so than non-FBs. FBs have a superior ability to identify opportunities and acquire knowledge outside their boundaries because of their non-economic goals. FBs are risk-averse, non-economic goals, and challenging to share control with non-family members (Casprini et al., 2017).

In contrast to corporate companies, innovation in FBs has been regarded as a waste of time and money. Innovation is valued as a key to long-term viability. In this regard, some authors suggest that FBs are less innovative because they prefer to avoid the risk of losing control rather than fail while trying new approaches (Gomez-Mejia et al., 2007). In contrast, other authors argue that many family-owned businesses are among the most innovative in their industries, even when they invest less in innovation because they are more efficient in their innovation processes due to more careful investments (Duran et al., 2016). 
From a generational point of view, Kammerlander and van Essen (2017) found that firms led by later-generation family members are more innovative than other firms, while firms led by their founders are less efficient concerning innovation. Nevertheless, the linkages between family firms and innovation have not been widely studied theoretically or empirically (Jalilvand et al., 2019). Family involvement in innovation processes has also been studied, showing that it directly affects innovation inputs, activities, outputs, and outcomes on the relationships between the technological steps to innovation (De Massis et al., 2013).

To resolve the innovation dilemma in FBs and identify promising opportunities that can boost family firms' innovation performance, Feranita et al. (2017) point out that innovation in FBs needs to be studied along with three perspectives: strategic, transactional, and relational. To complement this argument, Mueller et al. (2013) argue that FBs need to pursue exploratory and exploitative innovation strategies to be viable in an environment of technological change and intensified competition. However, success patterns remain unclear whether exploratory and exploitative innovations are equally successful in different institutional settings that affect the success derived from stakeholders' willingness to allocate resources to innovation types.

For instance, for European family businesses, one top priority is being more innovative. The study of KPMG Enterprise European Family Business Barometer (2019) mentions that for $72 \%$ of the European family business participating in this study, it is very important or extremely important to innovate in the next two years. Other results of this study expose that FBs recognize the importance of innovation and digitalization as enablers for growth. Most family businesses polled (86.2\%) plan to participate in the digital economy.

For the question: Where do they stand in their attempt to implement the strategy of innovation and digitalization? The answers were ambiguous and surprising: $25.7 \%$ responded that it is included in their strategic plan, but they have not mapped out a well-considered approach, and they are in the early stages of rolling out of the strategy; $22.8 \%$ are currently experimenting with technology and platforms to build their digital presence and enhance innovation; $10.9 \%$ have an extension of their business in the online environment, but it is not generating the returns expected; and surprisingly, only 5.0\% have established e-commerce and are already providing services online.

Thus, FBs tend to invest less in innovation (Sciascia et al., 2015), rely to a lesser extent on external sources of knowledge for technological collaborations (Kotlar et al., 2013; Nieto et al., 2015), and less inclined to adopt discontinuous technologies (Konig et al., 2013). Due to non-economic goals and the preservation of the family's socio-emotional wealth, family and non-family firms differ in their inclination to innovate (Naldi et al., 2013).

In pursuing innovation, FBs may rely on unique resources, such as familiness (Carnes \& Ireland, 2013; Pearson et al., 2008), tradition (De Massis et al., 2016), social capital (Habbershon \& Williams, 1999), and benefit from the alignment of incentives between owners and managers, thereby reducing agency costs and encouraging fast decision-making (Craig \& Dibrell, 2006). As such, FBs may leverage their unique characteristics to innovate. FBs tend to prefer using 
internal knowledge, thus adopting a more closed approach to innovation, unless specific knowledge management practices are adopted, such as the presence of intellectual property (IP) mechanisms (Kotlar et al., 2013). Firms often fail to execute an innovation strategy due to the knowledge management barriers they face (Verbano et al., 2015).

FBs must be aware that innovation only during crises might not be sustainable. Leppäaho and Ritala's (2021) recent study points out how a family firm increased its competitiveness in crises through a combination of tradition, innovation, and family leadership's perseverance. These authors found a preference reversal logic to family firms' long-term strategic behavior, corresponding to the behavioral change in risk preferences when family firms' performance falls below aspirations. For family firms, preference reversal implies a logic of organizational evolution in which calm periods facilitate stability and risk-aversion, while externally triggered crisis periods encourage innovation and exploration.

\section{IT to Enhance Knowledge Management in Family Firms}

The current economic environment demands the awareness of innovation and IT tools benefits for FBs. For instance, to provide practical insights for family business owners and managers, Diasio (2017) argues that inflows and outflows of knowledge within open innovation are relevant beyond product and service innovation. The application of emerging technology can support managerial decision-making, even though it is essential to have a digital strategy using useful websites, social media, and mobile applications.

FBs adopt ICT slowly compared with large companies, mainly referring to effective integrated systems that support business processes and enable management decisions that generate long-term turnover and profit rate effects. ICT can help an organization speed up disseminating information, integrate networking between firms, enable closer links between businesses and customers, reduce geographic boundaries, and increase communication efficiency (Spiezia, 2011). ICT can also be used to support data gathering and processing for making business decisions. Also, many owners/managers of small businesses are poor planners, mainly using DSSs that are much more user-friendly.

During the coronavirus pandemic, the use of digital technology has also kept people connected, offered innovative solutions to businesses, and allowed them to adapt quickly to market needs (Firfiray and Gomez-Mejia (2021). In a recent study, Leppäaho and Ritala (2021) identified that technological solid and digital innovation capabilities were crucial for FBs during the coronavirus pandemic, becoming a critical adaptive capacity for FB. Identifying digital artifacts and platforms allowed us to become flexible and react quickly to changing market requirements (Soluk et al., 2021).

Digital technologies offer new practices that provide entrepreneurial opportunities and enable the development of novel business models and value propositions that blend environmental, social, and economic values (Gregori \& Holzmann, 2020). Combining multiple digital artifacts and infrastructures (e.g., blogs, boards, 
Table 1 Knowledge management processes as adaptive capabilities for FBs

\begin{tabular}{|c|c|}
\hline $\begin{array}{l}\text { Family firms challenges to compete and survive } \\
\text { in uncertain times }\end{array}$ & $\begin{array}{l}\text { Knowledge management processes as adaptive } \\
\text { capabilities in uncertain times }\end{array}$ \\
\hline $\begin{array}{l}\text { Professionalization for an objective and fasten } \\
\text { decision making process }\end{array}$ & $\begin{array}{l}\text { Knowledge transfer: FBs carries a lot of tacit } \\
\text { knowledge to manage. Knowledge transfer allows } \\
\text { aligning the strategy with organizational structure: } \\
\text { board, leadership team, and operation } \\
\text { management }\end{array}$ \\
\hline Succession to preserve values and legacy & $\begin{array}{l}\text { Knowledge transfer: knowledge is accumulated } \\
\text { through generations. Transferring is required to } \\
\text { evolve through generations and, at the same time, } \\
\text { preserves values and legacy }\end{array}$ \\
\hline Innovation to compete and expand business model & $\begin{array}{l}\text { Knowledge creation. FBs must be aware that } \\
\text { innovation only during crises might not be } \\
\text { sustainable. FBs need to pursue exploratory and } \\
\text { exploitative innovation strategies to be viable in } \\
\text { an environment of technological change and } \\
\text { intensified competition }\end{array}$ \\
\hline $\begin{array}{l}\text { Technology and social media for communication } \\
\text { and transparency of managerial decision-making }\end{array}$ & $\begin{array}{l}\text { Knowledge utilization. The application of emerging } \\
\text { technology can support managerial } \\
\text { decision-making }\end{array}$ \\
\hline
\end{tabular}

social media interfaces, platforms, etc.) creates spaces for community interaction, engaging in co-creation activities, and broadening stakeholder integration. Digital technologies can enable the parallel growth of socioenvironmental and financial value. This brings the importance of digital technologies and their supportive function for sustainable business models (George et al., 2020).

Besides all these, the COVID-19 pandemic is severely testing the attributes that give family businesses a competitive edge. Combining an increasingly digitalized world with AI advancements provides enterprises with complex tasks. This strategic trend, known as hyper-automation, drives cost savings and is expected to save $20-30 \%$ of human effort. It is also enabling entirely new business models and ways of working. The ability to survive and prepare for the "new normal" is critical for business survival and all the people who rely on it.

Strategic decision-makers need to understand how to implement the new technologies to enhance efficiency, facilitate new business models, and deliver highly personalized customer experiences. For many organizations, neglecting hyperautomation will make them unable to compete in the market and become unappealing to consumers. Conversely, those who embrace this trend will thrive.

Fortunately, there are many readily available off-the-shelf AI-based components for image recognition, optical character recognition, natural language processing, and speech recognition, providing a relatively straightforward path to increasing the complexity of what can be automated. Firms must adapt to or shape their environments by identifying, creating, and exploiting opportunities. Table 1 summarizes how knowledge management processes evolve as adaptive capabilities for FBs to face uncertain times. 


\section{Conclusions and Future Research}

Organizations must be transparent in a pandemic to survive and overcome eventualities such as COVID-19. They must act agilely, creating a safe environment to make mistakes and accelerate planning cycles to reallocate and reconfigure resources more frequently. Constant changes request to transform us continuously, the invitation to organizations is to be simple, flexible, and agile: simplicity to understand the entire organization's course, flexibility to change fasten, and agility to transform promptly. All of this will be possible with a resilient organizational culture and a high commitment from senior management to promote and support the new guidelines.

Environmental adaptability is increasingly essential for FBs, and more research is needed to explore organizational knowledge capabilities. The business family's goal of preserving the company long-term and their desire for continuity indicates that family firms might maintain a strong need to develop adaptive capacity, particularly during crises. The success of family firms depends not only on their identification of innovation opportunities in the environment but also particularly on their realization of such opportunities.

Family firms have demonstrated the flexibility to transform and adapt because of their closeness to their processes and management and their social network inside and outside organizations that allow them to respond quickly to market needs based on a fast-making decisions process. FBs need to preserve their traditions, beliefs, and knowledge to support this flexibility. At the same time, family firms must reinforce adaptive capabilities to remain competitive but, most importantly, survive. In general, evidence has shown that even exogenous or endogenous crises can act as either catalysts or inhibitors to innovation. Therefore, the crisis context and resulting strategic responses create essential and exciting questions for family business scholars.

The most valuable aspect that family businesses have is knowledge. To succeed after the pandemic, FBs must continually learn, create, transfer, and apply their knowledge, responding quickly to changes and new market opportunities. A critical, adaptive capability to survive is the knowledge transfer between family members. In this regard, knowledge management processes allow FBs to be more strategic, as they facilitate the firm's succession process and professionalization. Moreover, knowledge management fosters entrepreneurial opportunities and, in turn, innovation and, at the same time, information technology.

There is limited understanding of how FBs implement their innovation decisions. Family firms that focus on socioemotional wealth fall below aspirations and are likely to shift toward a more innovative and risky approach. Therefore, the typical view of a traditional family firm implies that it underinvests in R\&D and innovation in stable times but then increases its risk-taking when necessary during crises (Leppäaho \& Ritala, 2021). There is a lack of research to understand the findings, practices, and processes associated with managing the knowledge flows through which FBs execute innovation strategies. 
FBs should build up capacities and capabilities that could provide different avenues of innovation and adaptation of IT and digital tools through a proactive approach to dealing with turbulent and uncertain times. COVID-19 has shown only one truth: more than a growth strategy; FBs need an innovation and digitalization strategy to compete and survive. Furthermore, to develop and reinforce innovative capabilities, FBs need to adopt technological advances, but this is only possible when risk-aversion and challenge for sharing control with non-family members diminish. In an incessantly shape-shifting globalized context, firms need to innovatively keep pace with the accelerating rate of change and explore new opportunities worldwide (Andriopoulos \& Lewis, 2010; Penney et al., 2018; Thrassou et al., 2014).

\section{References}

Ahonen, H., Engeström, Y., \& Virkkunen, J. (2000). Knowledge management-the second generation: Creating competencies with and between work communities in the competence laboratory. In Y. Malhotra (Ed), Knowledge management and virtual organizations (1st ed). IGI Global, 282-305.

Alonso, A. D., Kok, S., \& O'Shea, M. (2019). The family business, adversity and change: A dynamic capabilities and knowledge-based approach. Journal of General Management, 44(2), 96-109.

Andriopoulos, C., \& Lewis, M. W. (2010). Managing innovation paradoxes: Ambidexterity lessons from leading product design companies. Long Range Planning, 43(1), 104-122.

Arregle, J. L., Hitt, M. A., Sirmon, D. G., \& Very, P. (2007). The development of organizational social capital: Attributes of family firms. Journal of Management Studies, 44(1), 73-95.

Bañegil, T., Barroso, A., \& Sanguino, R. (2013). La gestión del conocimiento en las empresas familiares. In V. Fernandez (Ed.), Nuevas investigaciones sobre la gestión de la empresa familiar en España (pp. 69-84). OmniaScience.

Barroso, A., Sanguino, R., \& Bañegil, T. (2013). Study of factors influencing knowledge transfer in family firms. Intangible Capital, 9(4), 1216-1238.

Barroso, A., Sanguino, R., \& Bañegil, T. (2016). An empirical study about knowledge transfer, entrepreneurial orientation and performance in family firms. European Journal of International Management, 10(5), 534-557.

Basco, R., \& Pérez-Rodríguez, M. J. (2011). Ideal types of family business management: Horizontal fit between family and business decisions and the relationship with family business performance. Journal of Family Business Strategy, 2(3), 151-165.

Basco, R. (2015). Family business and regional development - A theoretical model of regional familiness. Journal of Family Business Strategy, 6(4), 259-271.

Botero, I. C., Barroso, A., Sanguino, R., \& Binhote, J. (2021). The family's effect on knowledge sharing in family firms. Journal of Knowledge Management. https://doi.org/10.1108/JKM-08-2020-0653.

Botero, I. C., Cruz, C., De Massis, A., \& Nordqvist, M. (2015). Family business research in the European context. European Journal of International Management, 9(2), 139-159.

Bouncken, R. B., Hughes, M., Ratzmann, M., Cesinger, B., \& Pesch, R. (2020). Family firms, alliance governance and mutual knowledge creation. British Journal of Management, 31(4), 769-791.

Brumana, M., Minola, T., Garrett, R. P., \& Digan, S. P. (2017). How do family firms launch new businesses? A developmental perspective on internal corporate venturing in family business. Journal of Small Business Management, 55(4), 594-613.

Burkart, M., Panunzi, F., \& Shleifer, A. (2003). Family firms. The. Journal of Finance, 58(5), 2167-2201.

Cabrera-Suárez, K., De Saá-Pérez, P., \& García-Almeida, D. (2001). The succession process from a resource-and knowledge-based view of the family firm. Family Business Review, 14(1), 37-46.

Camfield, C., \& Franco, M. (2019). Theoretical framework for family firm management: Relationship between personal values and professionalization and succession. Journal of Family Business Management, 9(2), 201-227. https://doi.org/10.1108/JFBM-06-2018-0020

Carayannis, E. G., Grigoroudis, E., Sindakis, S., \& Walter, C. (2014). Business model innovation as antecedent of sustainable enterprise excellence and resilience. Journal of the Knowledge Economy, 5(3), 440-463. 
Carnes, C. M., \& Ireland, R. D. (2013). Familiness and innovation: Resource bundling as the missing link. Entrepreneurship Theory and Practice, 37(6), 1399-1419.

Casprini, E., De Massis, A., Di Minin, A., Frattini, F., \& Piccaluga, A. (2017). How family firms execute open innovation strategies: The Loccioni case. Journal of Knowledge Management, 21(6), 1459-1485.

Chen, Y. M., Liu, H. H., Yang, Y. K., \& Chen, W. H. (2016). CEO succession in family firms: Stewardship perspective in the pre-succession context. Journal of Business Research, 69(11), 5111-5116.

Chirico, F. (2008). The creation, sharing and transfer of knowledge in family business. Journal of Small Business \& Entrepreneurship, 21(4), 413-433.

Chirico, F., \& Salvato, C. (2008). Knowledge integration and dynamic organizational adaptation in family firms. Family Business Review, 21(2), 169-181.

Chirico, F., \& Nordqvist, M. (2010). Dynamic capabilities and trans-generational value creation in family firms: The role of organizational culture. International Small Business Journal, 28(5), 487-504.

Craig, J., \& Dibrell, C. (2006). The natural environment, innovation, and firm performance: A comparative study. Family Business Review, 19(4), 275-288.

Cromie, S., Stephenson, B., \& Monteith, D. (1995). The management of family firms: An empirical investigation. International Small Business Journal, 13(4), 11-34.

Dekker, J. C., Lybaert, N., Steijvers, T., Depaire, B., \& Mercken, R. (2013). Family firm types based on the professionalization construct: Exploratory research. Family Business Review, 26(1), 81-99.

De Massis, A., Chua, J. H., \& Chrisman, J. J. (2008). Factors preventing intra-family succession. Family Business Review, 21(2), 183-199.

De Massis, A., Frattini, F., \& Lichtenthaler, U. (2013). Research on technological innovation in family firms: Present debates and future directions. Family Business Review, 26(1), 10-31. https://doi.org/ 10.1177/0894486512466258

De Massis, A., \& Frattini, F.M.,; Pizzurno, E., \& Cassia, L. (2015). Product innovation in family versus nonfamily firms: An exploratory analysis. Journal of Small Business Management, 53(1), 1-36.

De Massis, A., Frattini, F., Kotlar, J., Petruzzelli, A. M., \& Wright, M. (2016). Innovation through tradition: Lessons from innovative family businesses and directions for future research. Academy of Management Perspectives, 30(1), 93-116.

De Massis, A., \& Rondi, E. (2020). COVID-19 and the future of family business research. Journal of Management Studies, 57(8), 1727-1731.

Del Giudice, M., Della Peruta, M. R., \& Carayannis, E. G. (2010). Knowledge and the family business: The governance and management of family firms in the new knowledge economy. Springer.

Diasio, S. (2017). Open models of decision support: Towards a framework. ISPIM - International Society for Professional Innovation Management.

Diéguez-Soto, J., Manzaneque, M., \& Rojo-Ramírez, A. A. (2016). Technological innovation inputs, outputs, and performance: The moderating role of family involvement in management. Family Business Review, 29(3), 327-346.

Duran, P., Kammerlander, N., Van Essen, M., \& Zellweger, T. (2016). Doing more with less: Innovation input and output in family firms. Academy of Management Journal, 59(4), 1224-1264.

Fang, H., Memili, E., Chrisman, J. J., \& Welsh, D. H. B. (2012). Family firms' professionalization: Institutional theory and resource-based view perspectives. Small Business Institute Journal, 8(2), 12-34.

Feranita, I., Kotlar, J., \& De Massis, A. (2017). Collaborative innovation in family firms: Past research, current debates and agenda for future research. Journal of Family Business Strategy, 8, 137-156.

Firfiray, S., \& Gomez-Mejia, L. R. (2021). Can family firms nurture socioemotional wealth in the aftermath of Covid-19? Implications for research and practice. BRQ Business Research Quarterly, 23409444211008907.

Fuentes-Lombardo, G., Fernández-Ortiz, R., \& Cano-Rubio, M. (2011). Intangible assets in the internationalization of Spanish wineries: Directive and compared perception between family and non family businesses. Intangible Capital, 7(2), 428-473.

Giovannoni, E., Maraghini, M. P., \& Riccaboni, A. (2011). Transmitting knowledge across generations: The role of management accounting practices. Family Business Review, 24(2), 126-150.

Glyptis, L., Hadjielias, E., Christofi, M., Kvasova, O., \& Vrontis, D. (2021). Dynamic familiness capabilities and family business growth: A longitudinal perspective framed within management accounting. Journal of Business Research, 127, 346-363. 
Gómez-Mejía, L. R., Haynes, K. T., Núñez-Nickel, M., Jacobson, K. J., \& Moyano-Fuentes, J. (2007). Socioemotional wealth and business risks in family-controlled firms: Evidence from Spanish olive oil mills. Administrative Science Quarterly, 52(1), 106-137.

George, G., Lakhani, K. R., \& Puranam, P. (2020). What has changed? The impact of Covid pandemic on the technology and innovation management research agenda. Journal of Management Studies, 57(8), 1754.

Gregori, P., \& Holzmann, P. (2020). Digital sustainable entrepreneurship: A business model perspective on embedding digital technologies for social and environmental value creation. Journal of Cleaner Production, 272, 122817.

Habbershon, T. G., Williams, M., \& MacMillan, I. C. (2003). A unified systems perspective of family firm performance. Journal of Business Venturing, 18(4), 451-465.

Habbershon, T. G., \& Williams, M. L. (1999). A resource-based framework for assessing the strategic advantages of family firms. Family Business Review, 12(1), 1-25.

Helfat, C. E., \& Winter, S. G. (2011). Untangling dynamic and operational capabilities: Strategy for the (N) ever-changing world. Strategic Management Journal, 32(11), 1243-1250.

Hitt, M. A., Arregle, J. L., \& Holmes Jr, R. M. (2020). Strategic management theory in a post-pandemic and non-ergodic world. Journal of Management Studies.

Hoffman, J., Hoelscher, M., \& Sorenson, R. (2006). Achieving sustained competitive advantage: A family capital theory. Family Business Review, 19(2), 135-145.

Jalilvand, M. R., Vosta, L. N., Khalilakbar, R., Pool, J. K., \& Tabaeeian, R. A. (2019). The effects of internal marketing and entrepreneurial orientation on innovation in family businesses. Journal of the Knowledge Economy, 10, 1064-1079.

Kammerlander, N. \& van Essen, M. (2017). Family firms are more innovative than other companies. Harvard Business Review, Online.

König, A., Kammerlander, N., \& Enders, A. (2013). The family innovator's dilemma: How family influence affects the adoption of discontinuous technologies by incumbent firms. Academy of Management Review, 38(3), 418-441.

Kotlar, J., De Massis, A., Frattini, F., Bianchi, M., \& Fang, H. (2013). Technology acquisition in family and nonfamily firms: A longitudinal analysis of Spanish manufacturing firms. Journal of Product Innovation Management, 30(6), 1073-1088.

KPMG. (2019). European family business barometer, Retrieved December 1, 2019, from https://home. $\mathrm{kpmg} / \mathrm{xx} / \mathrm{en} / \mathrm{home} /$ services/enterprise/family-business.html

Le Breton-Miller, I., \& Miller, D. (2006). Why do some family businesses out-compete? Governance, long-term orientations, and sustainable capability. Entrepreneurship Theory and Practice, 30(6), 731-746.

Leppäaho, T., \& Ritala, P. (2021). Surviving the coronavirus pandemic and beyond: Unlocking family firms' innovation potential across crises. Journal of Family Business Strategy, 100440.

Letonja, M., \& Duh, M. (2016). Knowledge transfer in family businesses and its effects on the innovativeness of the next family generation. Knowledge Management Research \& Practice, 14(2), 213-224.

Martinez-Conesa, I., Soto-Acosta, P., \& Carayannis, E. G. (2017). On the path towards open innovation: Assessing the role of knowledge management capability and environmental dynamism in SMEs. Journal of Knowledge Management, 21(3), 553-570.

Mazzola, P., Marchisio, G., \& Astrachan, J. (2008). Strategic planning in family business: A powerful developmental tool for the next generation. Family Business Review, 21(3), 239-258.

Miroshnychenko, I., De Massis, A., Miller, D., Barontini, R. (2020). Family business growth around the world. Entrepreneurship Theory and Practice, 1-27. https://doi.org/10.1177/1042258720

Morgan, T. J., \& Gomez-Mejia, L. R. (2014). Hooked on a feeling: The affective component of socioemotional wealth in family firms. Journal of Family Business Strategy, 5(3), 280-288.

Mueller, V., Rosenbusch, N., \& Bausch, A. (2013). Success patterns of exploratory and exploitative innovation. A Meta-Analysis of the Influence of Institutional Factors. Journal of Management, 39(6), 1606-1636.

Naldi, L., Cennamo, C., Corbetta, G., \& Gomez-Mejia, L. (2013). Preserving socioemotional wealth in family firms: Asset or liability? The moderating role of business context. Entrepreneurship Theory and Practice, 37(6), 1341-1360.

Nieto, M. J., Santamaria, L., \& Fernandez, Z. (2015). Understanding the innovation behavior of family firms. Journal of Small Business Management, 53(2), 382-399.

Nonaka, I. (1991). The knowledge creating company. Harvard Business Review, 96-104. 
Nonaka, I., \& Takeuchi, H. (1995). The knowledge-creating company: How Japanese companies create the dynamics of innovation. Oxford University Press.

Pittino, D., Visintin, F., \& Lauto, G. (2017). A configurational analysis of the antecedents of entrepreneurial orientation. European Management Journal, 35(2), 224-237.

Pearson, A. W., Carr, J. C., \& Shaw, J. C. (2008). Toward a theory of familiness: A social capital perspective. Entrepreneurship Theory \& Practice, 32(6), 949-970.

Penney, C. R., Combs, J. G., Gaffney, N., \& Sexton, J. C. (2018). A jack-of-all-trades or a master of none: The performance effects of balancing exploration and exploitation within vs across alliance portfolio domains. Journal of Knowledge Management, 24(3), 569-587.

Polat, G. (2020). Advancing the multidimensional approach to family business professionalization. Journal of Family Business Management, Vol. ahead-of-print No. ahead-of-print. https://doi.org/10. 1108/JFBM-03-2020-0020

Sciascia, S., Nordqvist, M., Mazzola, P., \& De Massis, A. (2015). Family ownership and R\&D intensity in small-and medium-sized firms. Journal of Product Innovation Management, 32(3), 349-360.

Sirmon, D. G., \& Hitt, M. A. (2003). Managing resources: Linking unique resources, management, and wealth creation in family firms. Entrepreneurship Theory and Practice, 27(4), 339-358.

Soluk, J., Kammerlander, N., \& De Massis, A. (2021). Exogenous shocks and the adaptive capacity of family firms: exploring behavioral changes and digital technologies in the COVID-19 pandemic. $R \& D$ Management.

Songini, L., \& Gnan, L. (2015). Family involvement and agency cost control mechanisms in family small and medium-sized enterprises. Journal of Small Business Management, 53(3), 748-779.

Spiezia, V. (2011). Are ICT users more innovative? An analysis of ICT-enabled innovation in OECD firms. OECD Journal: Economic Studies, 1, 99-119.

Su, E., \& Daspit, J. (2021). Knowledge management in family firms: A systematic review, integrated insights and future research opportunities. Journal of Knowledge Management.

Tagiuri, R., \& Davis, J. (1996). Bivalent attributes of the family firm. Family Business Review, 9(2), 199-208.

Teece, D. J. (2007). Explicating dynamic capabilities: The nature and microfoundations of (sustainable) enterprise performance. Strategic Management Journal, 28(13), 1319-1350.

Thrassou, A., Vrontis, D., \& Bresciani, S. (2014). Strategic reflexivity in the hotel industry: A valuebased analysis. World Review of Entrepreneurship, Management and Sustainable Development, 10, 352-371.

Verbano, C., Crema, M., \& Venturini, K. (2015). The identification and characterization of open innovation profiles in Italian small and medium-sized enterprises. Journal of Small Business Management, 53(4), 1052-1075.

Vozikis, G. S., Liguori, E. W., Gibson, B., \& Weaver, K. M. (2012). Reducing the hindering forces in "intra-family business succession. American Journal of Economics and Business Administration, 4(1), 94-104.

Winter, S. G. (2003). Understanding Dynamic Capabilities. Strategic Management Journal, 24(10), 991-995.

Zahra, S. A., Neubaum, D. O., \& Larrañeta, B. (2007). Knowledge sharing and technological capabilities: The moderating role of family involvement. Journal of Business Research, 60(10), 1070-1079.

Publisher's Note Springer Nature remains neutral with regard to jurisdictional claims in published maps and institutional affiliations. 


\section{Authors and Affiliations}

Laura Zapata-Cantu ${ }^{1}$ Ramón Sanguino² $\cdot$ Ascensión Barroso²

Laura Nicola-Gavrilă

Ramón Sanguino

sanguino@unex.es

Ascensión Barroso

abarrosom@unex.es

Laura Nicola-Gavrilă

laura.gavrila@spiruharet.ro

1 EGADE Business School, Tecnológico de Monterrey, San Pedro Garza García, Nuevo León, Mexico

2 University of Extremadura, Badajoz, Spain

3 Spiru Haret University, Bucharest, Romania 